Jurnal Akuntansi \& Perpajakan, Volume 3, No. 1, Januari 2021

\title{
PENGARUH UKURAN DEWAN DIREKSI, UMUR PERUSAHAAN, DAN KEPEMILIKAN SAHAM PUBLIK TERHADAP CORPORATE SOCIAL RESPONSIBILITY DISCLOSURE
}

\author{
Merna \\ Fakultas Ilmu Sosial dan Humaniora Program Studi Akuntansi-Universitas Bunda Mulia \\ (Lodan Raya No 2, Jakarta Utara) \\ mernasurjadi@gmail.com
}

\begin{abstract}
ABSTRAK
Tujuan penelitian ini adalah untuk mengetahui tanggung jawab sosial perusahaan (corporate social resposibility) yang dilihat dari beberapa faktor, yaitu: ukuran dewan direksi, umur perusahaan, dan kepemilikan saham publik pada perusahaan go public yang terdaftar di Bursa Efek Indonesia periode 2014-2018. Studi ini juga menguji dan menganalisis pengaruh ukuran dewan direktur, umur perusahaan, dan kepemilikan saham publik terhadap corporate social responsibility disclosure. Sampel yang digunakan pada penelitian ini adalah perusahaan go publik yang terdaftar di Indonesia Stock Exchange (IDX) untuk periode 2014-2018. Jumlah perusahaan yang dijadikan sampel dalam penelitian ini adalah 22 perusahaan, dengan periode pengambilan data yang digunakan selama 5 (lima) tahun pengamatan, dan menggunakan metode purposive sampling. Metode ini dilakukan dengan tujuan untuk mendapatkan sampel yang representatif sesuai dengan kriteria yang ditentukan oleh peneliti. Jenis data yang digunakan yaitu data sekunder berupa laporan tahunan (annual report) perusahaan dan data laporan keberlanjutan perusahaan (sustainability report). Berdasarkan hasil pengujian yang menggunakan regresi linier berganda, dapat disimpulkan bahwa: (1) ukuran dewan direksi berpengaruh signifikan dan negatif terhadap corporate social responsibility disclosure ; (2) umur perusahaan tidak berpengaruh terhadap corporate social responsibility disclosure; dan (3) kepemilikan saham publik tidak berpengaruh terhadap corporate social resposibility disclosure.
\end{abstract}

Kata Kunci: ukuran dewan direksi, umur perusahaan, kepemilikan saham publik, corporate social responsibility disclosure

\begin{abstract}
The purpose of this study is to determine corporate social responsibility as seen from several factors, namely: board of directors size, company age, and public share ownership in go public companies listed on the Indonesia Stock Exchange for the 2014-2018 period. This study also examines and analyzes the effect of board of directors size, company age, and public share ownership on corporate social responsibility disclosure. The sample used in this study is a go public company listed on the Stock Exchange (IDX) for the 2014-2018 period. The number of companies sampled in this study were 22 companies, with the data collection period used for 5 (five) years of observation, and using purposive sampling method. This method is carried out in order to obtain a representative sample according to the criteria determined by the researcher. The type of data used is secondary data in the form of company annual reports and company sustainability report data. Based on the test results using multiple linear regression, it can be concluded that: (1) board of directors size has a significant and negative effect on corporate social responsibility disclosure; (2) company age has no effect on disclosure of corporate social responsibility; and (3) public share ownership has no effect on disclosure of corporate social responsibility.

Keywords: board of directors size, company age, and public share ownership, corporate social responsibility disclosure
\end{abstract}


Jurnal Akuntansi \& Perpajakan, Volume 3, No. 1, Januari 2021

\section{Pendahuluan}

Sebuah organisasi bisnis yang dikenal dengan sebutan perusahaan, merupakan salah satu entitas ekonomi dengan memiliki tujuan jangka panjang dan tujuan jangka pendek yang ingin dicapainya. Tujuan utama perusahaan dalam jangka panjang adalah untuk memaksimalkan nilai perusahaan dan memberikan insentif bagi para pemegang saham, sedangkan tujuan perusahaan dalam jangka pendek adalah memaksimalkan laba yang diperoleh melalui pemanfaatan sumber daya secara efisien. Dalam rangka untuk memberikan sinyal positif kepada para investor, perusahaan go public akan berusaha untuk meningkatkan nilai perusahaan melalui perbaikan kinerja perusahaan dengan berusaha untuk terus berkembang maju agar dapat bertahan dalam persaingan baik itu persaingan di negaranya sendiri ataupun di lingkungan global. Untuk mewujudkan hal tersebut manajemen akan mendorong aktivitas ekonomi yang dilakukan perusahaan tidak hanya fokus meningkatkan laba bagi kesejahteraan para pemegang saham, tetapi perusahaan juga harus memperhatikan aktivitas ekonomi yang berpengaruh merusak kelestarian lingkungan sekitar. Maka agar sebuah perusahaan dapat bersaing, maka perusahaan tersebut dituntut untuk memiliki komitmen dan kepedulian terhadap lingkungan sebagai salah satu cara adanya keberlanjutan dari kegiatan operasional perusahaan.

Meningkatnya kesadaran masyarakat akan dampak kegiatan operasional perusahaan yang berpotensi merusak lingkungan sekitarnya, secara tidak langsung mengubah sudut pandang perusahaan. Tanggung jawab sosial tidak lagi dipandang sebagai biaya yang menurunkan laba, namun sebagai investasi untuk dapat meningkatkan citra baik di mata masyarakat sehingga dapat meningkatkan laba jangka panjang juga untuk mempertahankan legitimasi dan going concern perusahaan. Oleh sebab itu perusahaan berkewajiban memperhatikan dampak sosial dan lingkungan dengan menerapkan tanggung jawab sosial yang biasa disebut Corporate Social Responsibility. Corporate Social Responbility apabila dipraktekkan dengan sungguh-sungguh akan memberikan dampak positif diantaranya: dapat 
Jurnal Akuntansi \& Perpajakan, Volume 3, No. 1, Januari 2021

mempererat komunikasi dengan stakeholders, mendorong perbaikan perusahaan secara berkesinambungan sebagai wujud manajemen risiko untuk melindungi reputasi, meningkatkan akses modal, memperbaiki kinerja keuangan, serta meningkatkan penjualan dan loyalitas pelanggan.

Pemerintah melalui Peraturan Pemerintah (PP) Nomor 47 tahun 2012, mendorong untuk dapat meningkatkan kesadaran perseroan (perusahaan) terhadap pelaksanaan tanggung jawab sosial dan lingkungan di Indonesia sehingga perusahaan tidak hanya dituntut mencari keuntungan atau laba semata, namun juga harus memperhatikan tanggung jawab sosial terhadap masyarakat. Perusahaan harus memberikan kontribusi secara langsung kepada masyarakat dengan meningkatkan kualitas kehidupan masyarakat dan lingkungannya. Menurut penelitian yang dilakukan oleh Hadi (2014), mengungkapkan bahwa Social Responsibility dengan perjalanan waktu menjadi bagian yang tak terpisahkan dari keberadaan perusahaan. Hal itu karena keberadaan perusahaan ditengah lingkungan memiliki dampak positif maupun negatif. Khusus dampak negatif (negative externalities) akan memicu reaksi dan protes stakeholder, sehingga perlu penyeimbangan melalui peran social responsibility sebagai salah satu strategi legitimasi perusahaan.

Melalui Undang- Undang No. 40 Tahun 2007 pasal 74 Tentang Tanggung Jawab Sosial dan Lingkungan, pemerintah mengupayakan agar perusahaan menerapkan Corporate Social Responsibility dalam program kerjanya dan mengungkapkan laporan pertanggung jawab sosialnya pada laporan tahunan perusahaan. Pengungkapan tanggung jawab sosial perusahaan atau Corporate Social Responsibility Disclosure (CSRD) merupakan suatu mekanisme yang digunakan oleh perusahaan untuk berkomunikasi dengan stakeholder dan digunakan untuk memberikan keuntungan atau memperbaiki legitimasi bagi perusahaan (Felita, 2016). Dampak positif yang ditimbulkan oleh perusahaan saat melakukan pengungkapan Corporate Social Responsibility membuat perusahaan termotivasi untuk memperluas tanggung jawab sosialnya. Praktik dan pengungkapan Corporate Social Responsibility ini, jika dilakukan secara berkesinambungan akan memberikan 
Jurnal Akuntansi \& Perpajakan, Volume 3, No. 1, Januari 2021

banyak manfaat bagi perusahaan. (Rakhienah dalam Hariyanto, 2016).

Selain menerapkan Corporate Social Responsibility, perusahaan juga perlu untuk menerapkan Good Corporate Governance dalam rangka pengelolaan perusahaan yang baik. Penelitian ini menggunakan good corporate governance sebagai faktor yang dapat mempengaruhi pengungkapan Corporate Social Responsibility. Menurut penelitian yang dilakukan oleh Sabirin (2016) Good Corporate Governance merupakan seperangkat peraturan yang mengatur hubungan antara pemegang saham, manajer, kreditur, pemerintah, karyawan, dan stakeholders lainnya agar seimbang hak dan kewajibannya. Perusahaan harus memperhatikan hal tersebut karena dalam kegiatan operasionalnya perusahaan tidak bergerak sendiri, melainkan bersama para stakeholders. Oleh karena itu perusahaan harus menjaga relasi tersebut agar secara timbal balik, baik perusahaan maupun stakeholders tidak ada yang dirugikan.

Karakteristik corporate governance yang pertama adalah ukuran dewan direksi sebagai elemen tertinggi dari pihak manajemen bertanggung jawab atas perolehan legitimasi dari seluruh pemangku kepentingan. Direksi merupakan organ perusahaan yang berwenang dan bertanggung jawab penuh atas pengelolaan untuk kepentingan perusahaan, sesuai dengan maksud dan tujuan mewakili perusahaan baik di dalam maupun di luar pengadilan, memimpin dan menyelenggarakan kegiatan operasional sesuai misi dan visi perusahaan serta memelihara dan mengurus kekayaan perusahaan, berdasarkan asas manfaat, adil dan merata, kepastian hukum, keamanan, kemitraan, etika, dan kepercayaan pada diri sendiri serta memastikan konsistensi penerapan good corporate governance (GCG).

Variabel berikutnya yang digunakan dalam penelitian ini untuk menjelaskan pengungkapan Corporate Social Responsibility disclosure adalah umur perusahaan. Menurut penelitian yang dilakukan oleh Purwanti (2019), umur perusahaan merupakan lamanya perusahaan terdaftar di Bursa Efek Indonesia. Semakin lama umur listing perusahaan menunjukkan bahwa perusahaan dapat bertahan di tengah persaingan bisnis dan berpengalaman, maka semakin besar pula pengungkapan 
Jurnal Akuntansi \& Perpajakan, Volume 3, No. 1, Januari 2021

tanggung jawab sosial perusahaan. Perusahaan yang sudah lama listing diasumsikan telah memiliki banyak pemangku kepentingan (stakeholder), sehingga tingkat pengungkapan tanggung jawab sosial perusahaan semakin meningkat dan akan semakin baik..

Menurut penelitian ilmiah terdahulu yang dilakukan oleh Rifqiyah (2016), bahwa kepemilikan saham publik (public shareholding) adalah proporsi kepemilikan saham yang dimiliki oleh publik atau masyarakat terhadap saham perusahaan. Pengertian publik disini adalah pihak individu atau institusi yang memiliki saham dibawah $5 \%(<5 \%)$ yang berada di luar manajemen dan tidak memiliki hubungan istimewa dengan perusahaan. Menurut penelitian yang dilakukan oleh Hamdani, et al (2017), hubungan antara kepemilikan saham publik dengan pengungkapan Corporate Social Responsibility menunjukan hasil bahwa semakin besar proporsi kepemilikan saham publik, semakin banyak informasi tentang perusahaan, dan semakin banyak butir yang diungkapkan pada laporan tahunan serta semakin luas pula pengungkapan tanggung jawab sosialnya.
Berdasarkan latar belakang di atas dan beberapa penelitian yang sudah dilakukan oleh peneliti sebelumnya yang masih inkonsistensi, maka peneliti termotivasi ingin menguji dan menganalisis kembali ukuran dewan direksi, umur perusahaan dan kepemilikan saham publik terhadap pengungkapan tanggung jawab sosial perusahaan (Corporate Social Responsibility Disclosure).

\section{IL Landasan Teori}

\section{Teori Legitimasi}

Teori legitimasi adalah sistem pengelolaan perusahaan yang berorientasi pada keberpihakan terhadap masyarakat (society), pemerintah, individu dan kelompok masyarakat (Hadi, 2014, p88). Untuk itu, sebagai suatu sistem yang mengutamakan keberpihakan kepada kepentingan masyarakat, operasi perusahaan harus sesuai dengan harapan dari masyarakat. Berdasarkan pendapat Dowling dan Preffer (1975) dalam penelitian Prasista dan Setiawan (2016, p2127) menjelaskan bahwa terdapat dua aspek agar perusahaan memperoleh dukungan legitimasi. Pertama, aktivitas organisasi harus sesuai dengan sistem nilai di masyarakat, dan kedua, pelaporan 
Jurnal Akuntansi \& Perpajakan, Volume 3, No. 1, Januari 2021

aktivitas perusahaan juga hendaknya mencerminkan nilai sosial.

Menurut Krisna dan Suhardianto (2016, p120), semakin besar sumber daya yang dimiliki perusahaan, maka semakin besar upaya perusahaan untuk memperoleh legitimasi dari seluruh pemangku kepentingan. Menurut Barkemeyer (2007) dalam penelitian Sudjana dan Sudana (2017, p2470), mengungkapkan bahwa kekuatan teori legitimasi pada organisasi dalam konteks CSR perusahaan di negara berkembang ada dua hal, yaitu kapabilitas untuk menempatkan motif maksimalisasi keuntungan perusahaan sehingga memberikan gambaran yang lebih jelas mengenai motivasi perusahaan untuk memperluas CSR dan legitimasi organisasi juga dapat untuk memasukkan faktor budaya yang membentuk tekanan institusi yang berbeda dalam konteks yang berbeda.

\section{Teori Stakeholder}

Menurut Ghozali dan Chariri (2007) dalam penelitian Trinanda, et al. (2018), teori stakeholder mengungkapkan bahwa perusahaan bukan hanya entitas yang beroperasi guna kepentingan sendiri tetapi harus memberikan manfaat bagi stakeholdernya. Dengan demikian, eksistensi suatu perusahaan adalah mempunyai pengaruh berupa dukungan yang diserahkan oleh stakeholder atas perusahaan itu.

Menurut Clarkson dalam penelitian Trinanda, et a.l (2018), stakeholder dibagi menjadi dua, yakni stakeholder sekunder dan stakeholder primer. Stakeholder primer adalah pihak dimana tanpa ada partisipasinya yang berkelanjutan maka perusahaan tidak dapat bertahan. Contohnya pemilik modal atau saham, kreditor, karyawan, konsumen, pemasok, penyalur atau rekanan. Sedangkan stakeholder sekunder didefinisikan sebagai suatu pihak yang mempengaruhi dan/atau dipengaruhi oleh perusahaan tetapi mereka tidak langsung dilibatkan dalam transaksi dengan perusahaan atau tidak berkepentingan dalam kelangsungan operasional perusahaan. Contohnya, Pemerintah setempat, media massa, kelompok sosial, anggota pendukung dan masyarakat. Stakeholder pada dasarnya bisa mengendalikan atau memiliki keahlian untuk mempengaruhi penggunaan sumber-sumber ekonomi yang dipakai perusahaan.

Berdasarkan asumsi dasar stakeholder theory, perusahaan tidak dapat 
Jurnal Akuntansi \& Perpajakan, Volume 3, No. 1, Januari 2021

melepaskan diri dengan lingkungan sosial sekitarnya. Perusahaan perlu menjaga legitimasi stakeholder serta mendudukannya dalam kerangka kebijakan dan pengambilan keputusan, sehingga dapat mendukung dalam pencapaian tujuan perusahaan, yaitu stabilitas usaha dan jaminan going concern Hadi (2014).

\section{Ukuran Dewan Direksi}

Ukuran Dewan Direksi menurut UndangUndang Nomor 40 Tahun 2007 tentang perseoran terbatas adalah Direksi merupakan organ perseoran yang berwenang dan bertanggung jawab penuh atas pengurus perseoran untuk kepentingan perseoran, sesuai dengan maksud dan tujuan perseoran serta mewakili perseoran baik di dalam maupun di luar pengadilan sesuai dengan ketentuan anggaran dasar. Dewan direksi dalam suatu perusahaan akan menentukan kebijakan yang akan diambil atau strategi perusahaan tersebut secara jangka pendek maupun jangka panjang. Peningkatan ukuran dewan direksi akan memberikan manfaat bagi perusahaan karena tercipta network dengan pihak luar perusahaan dan menjamin ketersediaan sumberdaya.
Komite Nasional Kebijakan Governance (KNKG) menjelaskan bahwa direksi merupakan organ perusahaan yang bertugas dan bertanggung jawab secara kolegial dalam mengelola perusahaan serta masing-masing anggota direksi dapat melaksanakan tugas dan mengambil keputusan sesuai dengan pembagian tugas dan wewenangnya. Ukuran dewan direksi dapat diukur dengan jumlah dewan direksi dalam perusahaan dimana semakin banyak dewan dalam suatu perusahaan akan memberikan suatu bentuk pengawasan terhadap kinerja perusahaan yang semakin lebih baik.

\section{Umur Perusahaan}

Menurut Untari (2010) dalam penelitian Sunaryo dan Mahfud (2016, p4), umur perusahaan juga merupakan faktor yang mempengaruhi kinerja perusahaan dalam mengungkapkan tangggung jawab sosialnya. Umur perusahaan dapat menunjukkan kemampuan dalam mengatasi kesulitan dan hambatan yang dapat mengancam kehidupan perusahaan, serta menunjukkan kemampuan perusahaan mengambil kesempatan dalam lingkungannya untuk mengembangkan usaha. Disamping itu, umur perusahaan dapat menunjukkan kemampuan dalam 
Jurnal Akuntansi \& Perpajakan, Volume 3, No. 1, Januari 2021

keunggulan berkompetisi.

Menurut Utami dan Prastiti (2011) dalam penelitian Sunaryo dan Mahfud (2016, p5), dengan demikian makin lama perusahaan berdiri kian menunjukkan eksistensinya dalam lingkungannya dan makin bisa meningkatkan kepercayaan investor. Umur perusahaan menunjukkan seberapa perusahaan mampu bertahan. Umur perusahaan diperkirakan memiliki hubungan positif dengan kualitas ungkapan sukarela. Hal ini dapat dikaitkan dengan teori legitimasi.

Menurut teori ini, legitimasi organisasi dapat dilihat sebagai sesuatu yang diberikan masyarakat kepada perusahaan dan sesuatu yang diinginkan atau dicari perusahaan dari masyarakat. Menurut Wulandari (2018, p5), didalam teori legitimasi dikatakan, apabila sistem sosial dan sistem perusahaan berjalan selaras, maka tidak ada ancaman terhadap legitimasi perusahaan. Salah satu cara untuk mendapat legitimasi tersebut adalah dengan melakukan pengungkapan tanggung jawab sosial perusahaan. Sehingga perusahaan yang telah lama berdiri biasanya dapat menghasilkan laba lebih tinggi dari pada perusahaan yang baru berdiri.

\section{Kepemilikan Saham Publik}

Menurut Rahayu dan Anisyukurlillah (2015, p3), perusahaan yang kepemilikan saham publiknya tinggi menunjukkan bahwa perusahaan dianggap mampu beroperasi dan memberikan deviden yang sesuai kepada masyarakat sehingga cenderung akan mengungkapkan informasi sosial yang lebih luas. Menurut Karnadjaja, et al. (2007) dalam penelitian Rahmayanty (2015, p3), kepemilikan saham oleh publik dalam hal ini diartikan sebagai seberapa banyak jumlah saham yang dimiliki oleh publik yang merupakan pihak individu di luar manajemen, dan tidak memiliki hubungan istimewa dengan perusahaan.

Adanya faktor kepemilikan publik, maka perusahaan harus menyajikan laporan tahunan perusahaan kepada publik untuk menjaga kepercayaan investor publik terhadap perusahaan. Menurut penelitian yang dilakukan oleh Aprifa dan Ardiyanto (2017), ketika perusahaan mulai go public, maka akuntabilitasnya terhadap masyarakat akan menjadi sangat penting. Oleh karena itu perusahaan dengan kepemilikan publik akan memiliki tekanan 
Jurnal Akuntansi \& Perpajakan, Volume 3, No. 1, Januari 2021

yang lebih besar untuk mengungkapkan informasi tambahan terkait dengan visibilitas dan akuntabilitas kepada sejumlah besar pemangku kepentingan.

\section{Corporate Social Responsibility (CSR)}

Menurut Hadi (2011) dalam penelitian Budiman (2015, p16), tanggung jawab sosial perusahaan adalah satu bentuk tindakan yang berangkat dari pertimbangan etis perusahaan yang diarahkan untuk meningkatkan ekonomi dengan peningkatan kualitas hidup bagi karyawan berikut dengan keluarganya, serta sekaligus peningkatan kualitas hidup masyarakat sekitar dan masyarakat lebih luas. Menurut Oktariani (2014) dalam penelitian Pradnyani dan Sisdyani (2015, p385), CSR dimaksudkan agar dunia usaha meminimalkan dampak buruk terhadap aspek sosial dan lingkungan yang ditimbulkan selama menjalankan seluruh aktivitasnya. Konsep CSR merupakan tanggung jawab perusahaan kepada para pengemban kepentingan (stakeholder) dan/atau pihak yang terkena dampak dari keberadaan perusahaan.

Adanya dampak dari aktivitas perusahaan telah menyadarkan bahwa kerusakan lingkungan yang terjadi bisa dikurangi agar dapat dimanfaatkan oleh generasi mendatang. Sedangkan menurut Darwin (2004) dalam penelitian Sunaryo dan Mahfud (2016, p3), Corporate Social Responsibility (CSR), dalam bahasa Indonesia dikenal dengan tanggung jawab sosial perusahaan. Pada intinya, diartikan sebagai upaya perusahaan untuk meningkatkan kepedulian terhadap masalah sosial dan lingkungan dalam kegiatan usaha dan juga pada cara perusahaan berinteraksi dengan stakeholders (pihak-pihak yang terkait dengan suatu isu atau rencana) yang dilakukan secara sukarela.

Selain itu, CSR diartikan pula sebagai komitmen bisnis untuk berkonstribusi dalam pembangunan ekonomi berkelanjutan, bekerja sama dengan para karyawan perusahaan, keluarga karyawan dan masyarakat setempat (lokal) dalam rangka meningkatkan kualitas kehidupan.

\section{Corporate Social Responsibility (CSR)} adalah mekanisme bagi suatu perusahaan untuk secara sukarela mengintergrasikan perhatian terhadap lingkungan dan sosial ke dalam operasinya dan interaksinya dengan stakeholders, yang melebihi tanggung jawab organisasi di bidang 
Jurnal Akuntansi \& Perpajakan, Volume 3, No. 1, Januari 2021

hukum.

\section{Road Map Penelitian}

Road Map penelitian ini dapat disusun sebagai berikut:

\begin{tabular}{ccc|}
$\begin{array}{c}\text { Perusahaan / } \\
\text { Entitas Bisnis }\end{array}$ & Dewan Direksi Umur \\
\hline Akuntansi Manajemen & Perusahaan \\
\hline Kepemilikan Saham Publik & $\begin{array}{c}\text { Corporate Social } \\
\text { Responsibility } \\
\text { Disclosure }\end{array}$ \\
\hline
\end{tabular}

\section{Desain Penelitian}

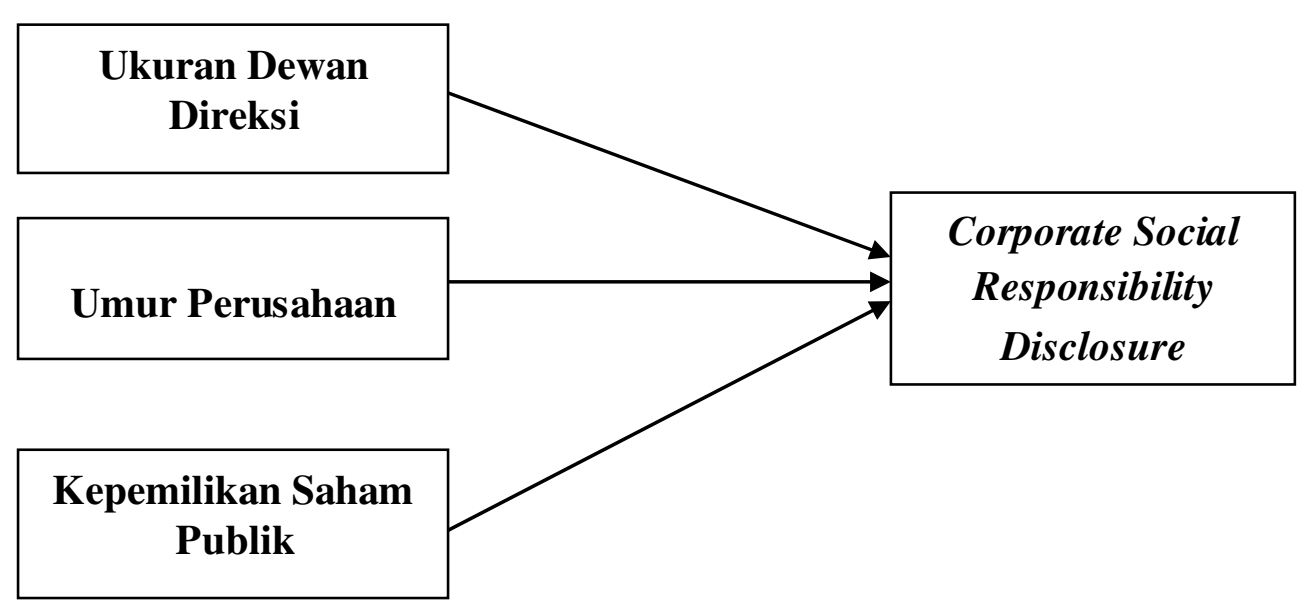


Jurnal Akuntansi \& Perpajakan, Volume 3, No. 1, Januari 2021

\section{Hipotesis Penelitian}

Berdasarkan paparan di atas, hipotesis yang akan diuji dalam penelitian ini adalah:

$\mathrm{H}_{1}$ : Ukuran Dewan Direksi mempunyai pengaruh secara signifikan terhadap Corporate Social Responsibility Disclosure.

$\mathrm{H}_{2}$ : Umur Perusahaan mempunyai pengaruh secara signifikan terhadap Corporate Social Responsibility Disclosure.

$\mathrm{H}_{3}$ : Kepemilikan Saham Publik mempunyai pengaruh secara signifikan terhadap

Corporate Social Responsibility Disclosure.

\section{III.METODE PENELITIAN}

\section{Prosedur Penelitian}

Menurut Ferdinan (2014) subjek adalah setiap anggota dari sampel, sama seperti elemen merupakan anggota dari setiap populasi. Subjek penelitian adalah orang, benda atau hal yang menjadi tempat melekatnya variabel penelitian yang dipermasalahkan. Di dalam penelitian ini yang menjadi subjek penelitian adalah perusahaan yang menerbitkan SR (sustainability report) yang terdaftar dalam Bursa Efek Indonesia pada periode 2014-2018. Dimana peneliti menggunakan data yang diperoleh dari website (www.idx.co.id) atau dengan mengunjungi website masing masing perusahaan yang bersangkutan. Karena data yang dibutuhkan dalam penelitian semua sudah dipublikasikan oleh perusahaan

Jenis penelitian yang digunakan adalah penelitian statistik deskriptif kuantitatif. Data kuantitatif, berupa angka-angka yang diperoleh dari laporan keuangan, sustainability report yang mencakup Corporate Social Responsibility report perusahaan kemudian dianalisis menggunakan statistik. Sumber data yang digunakan dalam penelitian ini adalah data sekunder. Data sekunder adalah data yang tidak didapatkan secara langsung dari sumbernya serta telah diolah pihak lain. Data sekunder dalam penelitian ini adalah laporan keberlanjutan Perusahaan pada periode tahun 2014-2018 yang terdaftar di Bursa Efek Indonesia. Data penelitian diperoleh dari website Bursa Efek Indonesia $\underline{w w w . i d x . c o . i d}$.

\section{Definisi Operationalisasi Variabel dan Pengukuran Variabel}

Variabel yang digunakan dalam penelitian ini adalah variabel independen dan variabel dependen. Variabel independen adalah variabel yang menjadi sebab atau mempengaruhi variabel dependen (Sujarweni, 2015). Variabel dependen merupakan variabel yang dipengaruhi 
Jurnal Akuntansi \& Perpajakan, Volume 3, No. 1, Januari 2021

atau menjadi akibat karena adanya variabel independen (Sujarweni, 2015).

Variabel independen dalam penelitian ini adalah Ukuran Dewan Direksi, Umur Perusahaan, dan Kepemilikan Saham Publik. Variabel dependen dalam penelitian ini adalah Corporate Social Responsibility Disclosure.

\section{Tabel 3.1}

\section{Tabel Operasionalisasi Variabel}

\begin{tabular}{|c|c|c|c|}
\hline $\begin{array}{c}\text { Variab } \\
\text { el }\end{array}$ & Definisi & $\begin{array}{l}\text { Skal } \\
\mathbf{a}\end{array}$ & $\begin{array}{l}\mathbf{R} \\
\mathbf{u} \\
\mathbf{m} \\
\mathbf{u} \\
\mathbf{S}\end{array}$ \\
\hline $\begin{array}{l}\text { Ukur } \\
\text { an } \\
\text { dew } \\
\text { an } \\
\text { dire } \\
\text { ksi } \\
\text { (X1) }\end{array}$ & $\begin{array}{l}\text { Ukuran } \\
\text { dewan } \\
\text { direksi } \\
\text { mencermin } \\
\text { kan } \\
\text { mekanisme } \\
\text { tata kelola } \\
\text { perusahaan } \\
\text { karena } \\
\text { pengambila } \\
\text { n } \\
\text { mempertim } \\
\text { bangkan } \\
\text { pendapat } \\
\text { anggota } \\
\text { direksi. } \\
\text { Semakin } \\
\text { besar } \\
\text { ukuran } \\
\text { dewan } \\
\text { direksi, } \\
\text { maka } \\
\text { semakin } \\
\text { besar } \\
\text { kemampua }\end{array}$ & $\begin{array}{c}R \\
a \\
t i \\
o\end{array}$ & $\begin{array}{c}\text { Dewan } \\
\text { Direksi } \\
= \\
\text { Jumlah } \\
\text { seluruh } \\
\text { anggot } \\
\text { a } \\
\text { dewan } \\
\text { direksi }\end{array}$ \\
\hline
\end{tabular}

\begin{tabular}{|c|c|c|c|}
\hline & $\mathrm{n}$ & & \\
\hline $\begin{array}{l}\text { Umu } \\
\text { r } \\
\text { Peru } \\
\text { saha } \\
\text { an } \\
(\mathrm{X} 2)\end{array}$ & $\begin{array}{l}\text { Seberapa } \\
\text { lama } \\
\text { perusahaan } \\
\text { mampu } \\
\text { bertahan di } \\
\text { pasar modal } \\
\text { (Budiman, } \\
\text { 2015). }\end{array}$ & $\begin{array}{c}R \\
a \\
t i \\
o\end{array}$ & $\begin{array}{l}A G E= \\
\text { Tahun ke-n } \\
\text { (tahun first } \\
\text { issue di BEI) } \\
\text { (Sulistyawati } \\
\text {, et al, 2016, } \\
\text { p471) }\end{array}$ \\
\hline $\begin{array}{c}\text { Kep } \\
\text { emili } \\
\text { kan } \\
\text { Saha } \\
\text { m } \\
\text { Publ } \\
\text { ik } \\
\text { (X3) }\end{array}$ & $\begin{array}{l}\text { Jumlah } \\
\text { saham yang } \\
\text { dimiliki } \\
\text { oleh publik } \\
\text { (Na'im \& } \\
\text { Rakhman } \\
\text { dalam } \\
\text { penelitian } \\
\text { Fatoni, et } \\
\text { al, 2016). }\end{array}$ & $\begin{array}{c}R \\
a \\
t i \\
o\end{array}$ & $\begin{array}{l}\text { (Rahayu } \\
\text { Anisyukurlill } \\
\text { ah, 2015, p5) }\end{array}$ \\
\hline $\begin{array}{l}\text { Corp } \\
\text { orate } \\
\text { Soci } \\
\text { al } \\
\text { Resp } \\
\text { onsib } \\
\text { ility } \\
\text { Discl } \\
\text { osur } \\
\text { e(Y) }\end{array}$ & $\begin{array}{l}\text { Tanggung } \\
\text { jawab } \\
\text { perusahaan } \\
\text { tidak hanya } \\
\text { terdapat } \\
\text { pemiliknya } \\
\text { atau } \\
\text { pemegang } \\
\text { saham saja } \\
\text { tetapi juga } \\
\text { terhadap }\end{array}$ & $\begin{array}{c}R \\
a \\
t i \\
o\end{array}$ & $\begin{array}{l}\quad \text { CSRI j } \\
\quad=\sum x \mathrm{ij} / \\
\quad \mathrm{n} \mathrm{j}\end{array}$ \\
\hline
\end{tabular}


Jurnal Akuntansi \& Perpajakan, Volume 3, No. 1, Januari 2021

\begin{tabular}{|l|l|l|}
\hline para & & \\
stakeholder & & \\
yang terkait & & \\
dan/atau & & \\
terkena & \\
dampak & & \\
dari & \\
keberadaan & & \\
perusahaan & & \\
(Felicia, et & & \\
al, 2015, & & \\
p143). & & \\
\hline
\end{tabular}

Sumber: data olahan peneliti (2020) 
Jurnal Akuntansi \& Perpajakan, Volume 3, No. 1, Januari 2021

\section{Teknik Analisis Data}

Analisis data secara statistika deskriptif merupakan analisis dengan cara mendeskripsikan atau menggambarkan data. Deskripsi data dilihat dari karakter data baik secara visual maupun secara numeris. Secara visual, deskripsi suatu data dapat digambarkan melalui diagram batang, garis, area, pie, boxplot, dan histogram. Secara numeris, analisis data secara deskriptif dilakukan dengan menelaah ukuran pusat dan penyebaran data. Ukuran pusat yang dihitung antara lain: rata-rata, median, modus, sedangkan ukuran penyebaran data di hitung dari range, standar deviasi, dan variansi.

\section{Uji Asumsi Klasik}

Pengujian asumsi klasik tersebut meliputi uji normalitas, uji multikolinearitas, uji heteroskedastisitas, dan uji autokorelasi.

\section{Uji Normalitas}

Menurut Pramesti (2014, p24), uji normalitas dilakukan untuk menyelidiki apakah data yang dikumpulkan terdistribusi normal atau tidak. Untuk melakukan uji normalitas dapat memakai Uji Kormogorov-Smirnov. Uji Kormogorov- Smirnov merupakan uji normalitas untuk sampel besar. Pada SPSS, jika dipilih tingkat signifikansi $\alpha=$ $0,05<$ nilai sig SPSS, maka dapat dikatakan bahwa data mengikuti distribusi normal.

\section{Uji Multikolinearitas}

Menurut Sunyoto (2016, p87), uji asumsi klasik jenis ini diterapkan untuk analisis regresi berganda yang terdiri atas dua atau lebih variabel bebas atau independen variabel, dimana akan di ukur keeratan hubungan antarvariabel bebas tersebut melalui besaran koefisien 
Jurnal Akuntansi \& Perpajakan, Volume 3, No. 1, Januari 2021

korelasi (r). Ada dua ukuran untuk untuk mengidentifikasi ada atau tidaknya multikolinier yaitu tolerance dan VIF. Model regresi dikatakan mengandung multikolinearitas apabila memiliki nilai tolerance $<0,10$ dan nilai VIF $>10$.

\section{Uji Heteroskedastisitas}

Menurut Ghozali (2016), uji Heteroskedastisitas bertujuan untuk menguji apakah dalam model regresi terjadi ketidaksamaan variance dari residual satu pengamatan ke pengamatan yang lain. Jika variance dari residual satu pengamatan ke pengamatan yang lain tetap, maka disebut homoskedastisitas dan jika berbeda disebut heteroskedastisitas. Model regresi yang baik adalah yang homoskedastisitas atau tidak terjadi heteroskedastisitas. Uji heteroskedastisitas dalam penelitian ini menggunakan grafik scatterplot. Dasar pengambilan keputusan dalam Uji Heteroskedastisitas dengan grafik scatterplot adalah jika terdapat pola tertentu pada Grafik Scatterplot SPSS, seperti titik-titik yang membentuk pola yang tertentu (bergelombang, menyebar kemudian menyempit) maka dapat disimpulkan bahwa telah terjadi heteroskedastisitas.Sebaliknya jika tidak ada pola yang jelas, serta titik-titik menyebar maka indikasinya adanya tidak terjadi heteroskedastisitas.

\section{Uji Autokorelasi}

Menurut Ghozali (2016, p108), uji autokorelasi bertujuan untuk menguji apakah dalam model regresi ada korelasi antara kesalahan pengganggu pada periode $\mathrm{t}$ dengan kesalahan pengganggu pada periode t-1 (sebelumnya). Model regresi yang baik adalah model regresi yang bebas dari autokorelasi. Alat ukur yang digunakan untuk mendeteksi adanya autokorelasi dalam penelitian ini menggunakan uji Durbin-Watson (DW), dengan kriteria pengambilan keputusan sebagai berikut:
a. Bila nilai DW antara du dan (4-du) berarti tidak terjadi autokorelasi.
b. Bila DW < dl berarti terjadi autokorelasi positif.
c. Bila DW > (4-dl) berarti terjadi autokorelasi negatif.
d. Bila DW antara (4-du) dan (4-dl) berarti hasil tidak dapat disimpulkan.

\section{Uji Analisis Regresi Linear Berganda}

Dalam penelitian ini penulis menggunakan analisis pengaruh, yaitu regresi linear berganda untuk menghubungkan satu variabel terikat (dependent) dan beberapa variabel bebas 
Jurnal Akuntansi \& Perpajakan, Volume 3, No. 1, Januari 2021

(independent). Pengunaan teknik linear berganda adalah untuk mengetahui apakah ada pengaruh antara satu variabel terikat dengan tiga variabel bebas. Rumus regresi linear berganda dalam penelitian ini adalah :

$$
\mathbf{Y}=\alpha+\beta_{1} \mathbf{X}_{1}+\beta_{2} X_{2}+\beta_{3} X_{3}+\varepsilon
$$

\section{Keterangan :}

$$
\boldsymbol{Y}=\text { Corporate Social Responsibility }
$$

Disclosure (CSRD)

$$
\begin{array}{ll}
\mathbf{X}_{\mathbf{1}} & =\text { Ukuran Dewan Direksi } \\
\mathbf{X}_{\mathbf{2}} & =\text { Umur Perusahaan } \\
\mathbf{X}_{\mathbf{3}} & =\text { Kepemilikan Saham Publik } \\
\boldsymbol{\alpha} & =\text { Konstanta }
\end{array}
$$$$
\boldsymbol{\beta}_{\mathbf{1}}, \boldsymbol{\beta}_{\mathbf{2}}, \boldsymbol{\beta}_{\mathbf{3}}=\text { Koefisien Regresi }
$$$$
\text { e }=\text { error }
$$

\section{Uji Koefisien Determinasi (Adj. $\mathbf{R}^{2}$}

Menurut Ghozali (2016), koefisien determinasi $\left(\mathrm{R}^{2}\right)$ pada intinya mengukur seberapa jauh kemampuan model dalam menerangkan kemampuan variasi variabel dependen. Nilai koefisien determinasi adalah antara nol dan satu. Pada penelitian ini digunakan nilai Adjusted $\mathrm{R}^{2}$ untuk mengukur besaranya koefisien determinasi. Jika $\mathrm{R}^{2}$ sama dengan 1, maka angka tersebut menunjukkan variabel variabel independen mempengaruhi variabel dependen secara sempurna. Nilai yang mendekati satu berarti variabel- variabel independen memiliki pengaruh yang terbaras terhadap variabel dependen.

\section{Uji F Simultan}

Menurut Ghozali (2016), uji F Simultan pada prinsipnya bertujuan untuk menguji signifikan secara serempak atau bersamasama semua variabel independen terhadap variabel dependen. Adapun kriteria pengambilan keputusan yaitu jika probabilitas $<0,05$ semua variabel independen dalam model ini mempunyai pengaruh secara bersama-sama terhadap variabel dependen.

\section{Uji Parsial (Uji t)}

Menurut Pramesti (2014), uji t dapat digunakan untuk menguji signifikansi rata-rata pada suatu sampel. Uji ini merupakan salah satu dari bentuk statistika parametrik. Menurut Ghozali (2016), adapun kriteria dalam pengambilan keputusan yaitu jika nilai signifikansi $>0,05$ maka tidak ada pengaruh secara parsial variabel independen pada variabel dependen, dan sebaliknya jika nilai signifikansinya < 0,05 maka ada pengaruh secara parsial variabel independen pada variabel dependen 
Jurnal Akuntansi \& Perpajakan, Volume 3, No. 1, Januari 2021

\section{HASIL DAN PEMBAHASAN}

\section{Penyajian Data}

Penelitian ini dilakukan dengan menggunakan data sekunder dimana datadata yang digunakan diperoleh dari website resmi Bursa Efek Indonesia (Indonesia Stock Exchange - www.idx.co.id). Data yang digunakan adalah laporan tahunan perusahaan yang terdaftar pada Indonesia Stock Exchange pada eriode 2014 - 2018. Dalam menentukan sampel penelitian, peneliti menggunakan teknik purposive sampling terhadap perusahaan yang terdaftar di Indonesia Stock Exchange (IDX).

Sampel adalah sebagian ciri atau karakteristik yang dimiliki oleh suatu populasi. Bisa juga dikatakan sampel merupakan bagian kecil yang diambil dari anggota populasi berdasarkan prosedur yang sudah ditentukan sehingga bisa digunakan untuk mewakili populasinya. Sampel dalam penelitian ini diambil dengan teknik purposive sampling, yaitu salah suatu teknik sampling non random dimana peneliti menentukan pengambilan sampel dengan cara menetapkan ciri-ciri khusus yang sesuai dengan tujuan penelitian sehingga diharapkan dapat menjawab permasalahan penelitian. Sampel dalam penelitian ini adalah Perusahaan yang terdaftar di Bursa Efek Indonesia pada periode 2014- 2018 dengan kriteria sebagai berikut:

1. Perusahaan yang terdaftar di Bursa Efek Indonesia periode 2014-2018.

2. Perusahaan yang menerbitkan Sustainability Report berturutturut selama periode 2014- 2018 yang terdaftar di Bursa Efek Indonesia.

3. Sustainability Report menggunakan standar yang diterapkan oleh Global Reporting Initiative (GRI) versi G4 berturutturut selama periode 2014-2018 yang terdaftar di Bursa Efek Indonesia.

4. Memiliki data yang lengkap terkait variabel-variabel yang digunakan dalam penelitian

Berikut ini adalah ringkasan hasil purposive sampling disajikan dalam tabel sebagai berikut: 
Jurnal Akuntansi \& Perpajakan, Volume 3, No. 1, Januari 2021

Tabel 4.1

Prosesv Pemilihan Sampel dengan Purposive Sampling

\begin{tabular}{|c|c|c|}
\hline \multicolumn{2}{|c|}{ No|Kriteria } & $\begin{array}{c}\text { Jumlah } \\
\text { Perusahaan }\end{array}$ \\
\hline 1 & $\begin{array}{l}\text { Perusahaan yang } \\
\text { terdaftar di BEI } \\
\text { yang menerbitkan } \\
\text { Sustainability } \\
\text { Report periode } \\
\text { 2014-2018 }\end{array}$ & 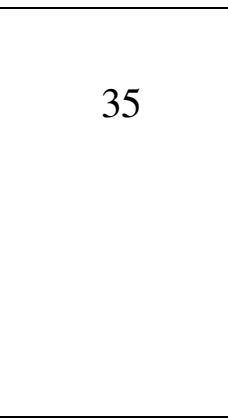 \\
\hline 2 & $\begin{array}{l}\text { Perusahaan tidak } \\
\text { menerapkan GRI versi } \\
\text { G4 } \\
\text { secara berturut turut } \\
\text { selama 2014-2018 }\end{array}$ & (8) \\
\hline 3 & $\begin{array}{l}\text { Perusahaan yang datanya } \\
\text { tidak lengkap untuk } \\
\text { penelitian }\end{array}$ & (5) \\
\hline 4 & $\begin{array}{l}\text { Perusahaan yang } \\
\text { menggunakan variabel } \\
\text { yang diteliti dalam } \\
\text { laporan yang diterbitkan } \\
\text { selama } \\
\text { periode 2014-2018 }\end{array}$ & 22 \\
\hline & Total sampel perusahaan & 22 \\
\hline & $\begin{array}{l}\text { Total sampel terpilih (5 } \\
\text { Tahun) }\end{array}$ & 110 \\
\hline
\end{tabular}

Sumber: Data diolah Penulis (2020)

\begin{abstract}
Statistik Deskriptif
Secara numeris, analisis data secara deskriptif dilakukan dengan memberikan gambaran atau deskripsi data berdasarkan nilai minimum, nilai maksimum, nilai ratarata (mean), dan standar deviasi dari masingmasing variabel yang diteliti.
\end{abstract}

\section{Tabel 4.2 Statistik Deskriptif}

\begin{tabular}{|c|c|c|c|c|c|}
\hline \multicolumn{6}{|c|}{ Descriptive Statistics } \\
\hline & $N$ & $\begin{array}{l}\text { Mini } \\
\text { mum }\end{array}$ & $\begin{array}{l}\text { Maxi } \\
\text { mum }\end{array}$ & $\begin{array}{l}\text { Me } \\
\text { an }\end{array}$ & $\begin{array}{l}\text { Std. } \\
\text { Deviati } \\
\text { on }\end{array}$ \\
\hline $\begin{array}{l}\text { Board_ } \\
\text { Dir }\end{array}$ & $\begin{array}{l}1 \\
1 \\
0 \\
\end{array}$ & $\begin{array}{r}4.0000 \\
0\end{array}$ & $\begin{array}{r}11.000 \\
00\end{array}$ & $\begin{array}{r}7.9000 \\
000\end{array}$ & $\begin{array}{r}1.87180 \\
921\end{array}$ \\
\hline $\begin{array}{l}\text { Age_Co } \\
\mathrm{mp}\end{array}$ & $\begin{array}{l}1 \\
1 \\
0 \\
\end{array}$ & $\begin{array}{r}3.0000 \\
0\end{array}$ & $\begin{array}{r}36.000 \\
00\end{array}$ & $\begin{array}{r}19.000 \\
0000\end{array}$ & $\begin{array}{r}8.49716 \\
628\end{array}$ \\
\hline $\begin{array}{l}\text { Pub_Ow } \\
\text { n }\end{array}$ & $\begin{array}{l}1 \\
1 \\
0\end{array}$ & $\begin{array}{r}1.6000 \\
0\end{array}$ & $\begin{array}{r}49.830 \\
00\end{array}$ & $\begin{array}{r}32.581 \\
0000\end{array}$ & $\begin{array}{r}12.7436 \\
5962\end{array}$ \\
\hline $\begin{array}{l}\text { Cor_So } \\
\text { sRes }\end{array}$ & $\begin{array}{l}1 \\
1 \\
0 \\
\end{array}$ & .05490 & .95600 & $\begin{array}{r}.36223 \\
31\end{array}$ & $\begin{array}{r}.184233 \\
41\end{array}$ \\
\hline $\begin{array}{l}\text { Valid N } \\
\text { (listwise } \\
\text { ) }\end{array}$ & $\begin{array}{l}1 \\
1 \\
0 \\
\end{array}$ & & & & \\
\hline
\end{tabular}

Sumber: Data primer olahan SPSS 24 (2020)

\section{Uji Asumsi Klasik}

\section{Uji Normalitas}

Uji normalitas digunakan untuk menguji apakah nilai residual yang dihasilkan dari modelr regresi terdistribusi secara normal 
Jurnal Akuntansi \& Perpajakan, Volume 3, No. 1, Januari 2021

atau tidak. Model regresi yang baik adalah yang memiliki nilai residual yang terdistribusi secara normal. Cara pengujian yang digunakan dalam penelitian ini adalah dengan menggunakann uji KolmogorovSmirnov (Priyatno, 2016).

Dari input data dan perhitungan yang dilakukan secara komputerisasi melalui program SPSS24.0 diperoleh hasil sebagai berikut

Uji Normalitas dengan metode Uji KolmogorovSmirnov (Liliefors Correction)

Tabel 4.3

HASIL UJI NORMALITAS (KolmogorovSmirnov)

\begin{tabular}{|c|c|c|}
\hline \multicolumn{3}{|c|}{$\begin{array}{l}\text { One-Sample Kolmogorov-Smirnov } \\
\text { Test }\end{array}$} \\
\hline & & $\begin{array}{l}\text { Unstandardized } \\
\text { Residual }\end{array}$ \\
\hline \multicolumn{2}{|l|}{$\mathrm{N}$} & 110 \\
\hline \multirow[t]{2}{*}{ Normal Parameters ${ }^{a, b}$} & Mean & .0000000 \\
\hline & $\begin{array}{l}\text { Std. } \\
\text { Deviation } \\
\end{array}$ & .17682449 \\
\hline \multirow{3}{*}{$\begin{array}{l}\text { Most Extreme } \\
\text { Differences }\end{array}$} & Absolute & .097 \\
\hline & Positive & .097 \\
\hline & Negative & -.052 \\
\hline \multicolumn{2}{|l|}{ Test Statistic } & .097 \\
\hline \multicolumn{2}{|l|}{ Asymp. Sig. (2-tailed) } & .133 \\
\hline \multicolumn{3}{|c|}{ a. Test distribution is Normal. } \\
\hline \multicolumn{3}{|c|}{ b. Calculated from data. } \\
\hline
\end{tabular}

Sumber: Data primer

olahan SPSS 24 (2020)

Berdasarkan hasil dalam Tabel 4.3 dapat kita lihat bahwa nilai signifikansi (Asymp. Sig. (2- tailed)) adalah 0,133 atau lebih besar dari 0,05 , yang artinya data yang digunakan untuk penelitian yang dilakukan pada perusahaan di Indonesia ini terdistribusi secara normal.

\section{Uji Multikolinearitas}

Menurut Ghozali (2016), uji multikolinearitas bertujuan untuk mengetahui apakah ada sebuah hubungan antar variabel independen dengan variabel independen lainnya. Model regresi yang baik adalah tidak adanya hubungan diantara variabel independen. Uji multikolineraritas digunakan untuk menguji apakah dalam model regresi ditemukan adanya korelasi yang tinggi antar variabel independen. Model regresi yang baik seharusnya tidak terjadi korelasi yang tinggi di antara variabel bebas. Metode pengujian yang biasa digunakan yaitu dengan melihat nilai Inflation Factor (VIF) dan Tolerance pada model regresi. Jika nilai VIF kurang dari 10 dan Tolerance lebih dari 0,1 maka model regresi bebas dari multikolineraritas (Priyatno, 2016). Hasil uji multikolinearitas dapat dilihat pada tabel berikut: 
Jurnal Akuntansi \& Perpajakan, Volume 3, No. 1, Januari 2021

Tabel 4.4

\section{UJI MULTIKOLINEARITAS}

\begin{tabular}{|c|c|c|c|c|c|c|c|}
\hline \multicolumn{8}{|c|}{ Coefficients $^{a}$} \\
\hline \multirow{3}{*}{ Model } & \multirow{2}{*}{\multicolumn{2}{|c|}{$\begin{array}{l}\text { Unstand } \\
\text { ardize } \\
d \\
\text { Coeffi } \\
\text { cients }\end{array}$}} & \multirow{2}{*}{$\begin{array}{l}\text { Standar } \\
\text { dized } \\
\text { Coeffic } \\
\text { ients }\end{array}$} & \multirow{3}{*}{$t$} & & \multirow{2}{*}{\multicolumn{2}{|c|}{$\begin{array}{l}\text { Collinearity } \\
\text { Statistics }\end{array}$}} \\
\hline & & & & & g & & \\
\hline & $B$ & $\begin{array}{l}\text { Std. } \\
\text { Error }\end{array}$ & $\begin{array}{l}B \\
\mathrm{e} \\
\mathrm{t} \\
\mathrm{a}\end{array}$ & & & $\begin{array}{r}\text { Tolera } \\
\text { nce }\end{array}$ & $\begin{array}{l}V \\
\text { I } \\
F\end{array}$ \\
\hline $\begin{array}{l}\text { (Const } \\
\text { ant) }\end{array}$ & $\begin{array}{l}.5 \\
45 \\
\end{array}$ & .094 & & $\begin{array}{r}5.7 \\
78 \\
\end{array}$ & $\begin{array}{r}.00 \\
0 \\
\end{array}$ & & \\
\hline $\begin{array}{l}\text { Board } \\
\text { Dir }\end{array}$ & $\begin{array}{l}- \\
.02 \\
2 \\
\end{array}$ & .009 & -.221 & $\begin{array}{r}-5 \\
2.3 \\
28 \\
\end{array}$ & $\begin{array}{r}.02 \\
2\end{array}$ & .961 & 1.041 \\
\hline $\begin{array}{l}\text { Age_C } \\
\text { omp }\end{array}$ & $\begin{array}{l}- \\
.00 \\
2\end{array}$ & .002 & -.107 & $\begin{array}{r}1.0 \\
93\end{array}$ & .27 & .906 & 1.104 \\
\hline $\begin{array}{l}\text { Pub_O } \\
\text { wn }\end{array}$ & $\begin{array}{l}.0 \\
01\end{array}$ & .001 & .072 & $\begin{array}{r}.74 \\
9\end{array}$ & $\begin{array}{r}.45 \\
5\end{array}$ & .941 & 1.063 \\
\hline
\end{tabular}

Sumber: Data primer olahan SPSS 24 (2020)

Dalam tabel diatas, dapat kita lihat bahwa tidak ada variabel independen yang memiliki nilai Tolerance kurang dari 0,1 dan tidak terdapat variabel independen yang memiliki nilai Variance Inflaction Factor (VIF) lebih dari 10. Jadi dapat disimpulkan bahwa tidak terdapat multikolinearitas antar variabel independen dalam model regresi.

\section{Uji Heteroskedastisitas}

Uji heteroskedastisitas digunakan untuk menguji apakah dalam model regresi terjadi ketidaksamaan varian dari residual pada satu pengamatan ke pengamatan yang lain.
Model regresi yang baik adalah tidak terjadi heteroskedastisitas (Priyatno, 2016). Pengujian ada tidaknya heteroskedastisitas pada penelitian ini menggunakan uji Glejser. Berikut disajikan hasil pengujian dengan uji Glejser.

\section{Tabel 4.5 \\ HASIL UJI HETEROSKEDASTISITAS (Glejser)}

\begin{tabular}{|c|c|c|c|c|c|}
\hline \multicolumn{6}{|c|}{ Coefficients $^{a}$} \\
\hline \multirow{11}{*}{ Model } & \multirow{10}{*}{\multicolumn{2}{|c|}{$\begin{array}{c}\text { Unst } \\
\text { an } \\
\text { dar } \\
\text { diz } \\
\text { ed } \\
\text { Co } \\
\text { effi } \\
\text { cie } \\
\text { nts }\end{array}$}} & Stand & \multirow{11}{*}{$\mathrm{t}$} & \\
\hline & & & & & \\
\hline & & & $r$ & & \\
\hline & & & d & & \\
\hline & & & $\mathrm{i}$ & & \\
\hline & & & $\mathrm{z}$ & & \\
\hline & & & $\mathrm{e}$ & & \\
\hline & & & & & \\
\hline & & & d & & \\
\hline & & & $\begin{array}{l}\text { Coeffic } \\
\text { ients }\end{array}$ & & \\
\hline & B & $\begin{array}{l}\text { Std. } \\
\text { Error }\end{array}$ & $\begin{array}{l}B \\
e \\
t \\
a\end{array}$ & & \\
\hline $\begin{array}{l}\text { (Cons } \\
\text { tant) }\end{array}$ & .294 & .054 & & $\begin{array}{l}5.4 \\
53\end{array}$ & $\begin{array}{r}.00 \\
0 \\
\end{array}$ \\
\hline $\begin{array}{l}\text { Board } \\
\text { _Dir }\end{array}$ & .027 & .005 & -.443 & $\begin{array}{r}-\overline{-} \\
84 \\
\end{array}$ & $\begin{array}{r}.30 \\
5\end{array}$ \\
\hline $\begin{array}{l}\text { Age } \\
\text { Comp }\end{array}$ & .002 & .001 & .159 & $\begin{array}{l}1.7 \\
34 \\
\end{array}$ & $\begin{array}{r}.28 \\
6 \\
\end{array}$ \\
\hline $\begin{array}{l}\text { Pub_- } \\
\text { Own }\end{array}$ & .000 & .001 & .043 & $\begin{array}{r}47 \\
7 \\
\end{array}$ & $\begin{array}{r}.63 \\
0 \\
\end{array}$ \\
\hline
\end{tabular}

Sumber: Data primer olahan SPSS 24 (2020)

Dari tabel di atas dapat diketahui bahwa nilai signifikan uji $\mathrm{t}$ semua variabel 
Jurnal Akuntansi \& Perpajakan, Volume 3, No. 1, Januari 2021

independen dengan Absolute Residual

(ABS_RES) lebih dari 0,05. Sehingga dapat

disimpulkan bahwa pada model regresi tidak ada masalah heteroskedastisitas.

\section{Uji Hipotesis}

\section{Hasil Analisis Regresi Linier Berganda}

Analisis regresi berganda digunakan untuk mengetahui hubungan antara ukuran dewan direksi, umur perusahaan, dan kepemilikan saham publik terhadap corporate social responsibility disclosure.

\section{Gambar 4.6}

Uji Regresi Linear Berganda

\begin{tabular}{|c|c|c|c|c|c|}
\hline \multicolumn{6}{|c|}{ Coefficients $^{a}$} \\
\hline \multirow[t]{2}{*}{ Model } & \multicolumn{2}{|c|}{$\begin{array}{l}\text { Unstandardize } \\
\qquad \begin{array}{l}\text { Coefficients } \\
\text { C }\end{array}\end{array}$} & \multirow{2}{*}{$\begin{array}{l}\text { Standardize } \\
\text { d } \\
\text { Coefficients } \\
\text { Bet } \\
\text { a } \\
\end{array}$} & \multirow[t]{2}{*}{$\mathrm{t}$} & \multirow[t]{2}{*}{ Sig. } \\
\hline & B & $\begin{array}{l}\text { Std. } \\
\text { Error }\end{array}$ & & & \\
\hline 1 (Constant) & .545 & .094 & & $\begin{array}{r}5.77 \\
8 \\
\end{array}$ & $\begin{array}{r}.00 \\
0 \\
\end{array}$ \\
\hline Board_Dir & .203 & .009 & .221 & $\begin{array}{r}2.32 \\
8 \\
\end{array}$ & $\begin{array}{r}.12 \\
2 \\
\end{array}$ \\
\hline $\begin{array}{l}\text { Age_Com } \\
p\end{array}$ & -.502 & .002 & -.107 & $\begin{array}{r}1.09 \\
3 \\
\end{array}$ & $\begin{array}{r}.27 \\
7\end{array}$ \\
\hline Pub_Own & .301 & .001 & .072 & .749 & $\begin{array}{r}.45 \\
5\end{array}$ \\
\hline a. Depende & riabl & Sos & & & \\
\hline
\end{tabular}

Sumber: Data olahan peneliti dari

Output SPSS 24.00 (2020)

Berdasarkan hasil pengujian pada gambar diatas, maka perhitungan regresi linear berganda menggunakan program SPSS didapatkan hasil sebagai berikut :
$\mathrm{Y}=0,545+0,203 \mathrm{X}_{1}-0,502 \mathrm{X}_{2}+0,301 \mathrm{X}_{3}+e$

Persamaan regresi diatas menunjukkan informasi sebagai berikut :

1. Nilai konstanta sebesar 0,545 . Hasil ini menunjukkan bahwa jika nilai seluruh variabel independen adalah 0 , maka nilai corporate social responsibility disclosure akan sebesar 0,545 .

2. Nilai koefisien regresi variabel ukuran dewan direksi sebesar 0,203. Hasil ini menunjukkan bahwa jika ukuran dewan direksi meningkat satu satuan maka corporate social responsibility disclosure akan meningkat sebesar 0,203 satuan dengan anggapan variabel lain tetap.

3. Nilai koefisien regresi variabel umur perusahaan sebesar $-0,502$. Hasil ini menunjukkan bahwa jika umur perusahaan meningkat satu satuan maka corporate social responsibility disclosure akan menurun sebesar 0,502 satuan dengan anggapan variabel lain tetap.

4. Nilai koefisien regresi variabel kepemilikan saham publik sebesar 0,301. Hasil ini menunjukkan bahwa jika kepemilikan saham publik meningkat satu satuan maka 
Jurnal Akuntansi \& Perpajakan, Volume 3, No. 1, Januari 2021

corporate social responsibility

disclosure akan meningkat sebesar 0,301 satuan dengan anggapan variabel lain tetap.

\section{Hasil Analisis Uji Kelayakan Model (Uji-F)}

Uji F dilakukan untuk menguji apakah model yang digunakan dalam penelitian ini adalah model yang layak dan apakah secara bersama-sama seluruh variabel independen mempunyai pengaruh yang signifikan terhadap variabel dependen. Berikut adalah hasil uji-F.

\section{Gambar 4.7 Hasil Uji-F}

\begin{tabular}{|c|c|c|c|c|c|}
\hline \multicolumn{6}{|c|}{ ANOVA $^{a}$} \\
\hline Model & $\begin{array}{l}\text { Sum } \\
\text { of } \\
\text { Squar } \\
\text { es }\end{array}$ & $\begin{array}{l}d \\
f\end{array}$ & $\begin{array}{l}\text { Me } \\
\text { an } \\
\text { Squ } \\
\text { are }\end{array}$ & $\mathrm{F}$ & Sig. \\
\hline $\begin{array}{l}\text { Regressi } \\
\text { on }\end{array}$ & .292 & 3 & .097 & $\begin{array}{l}3.0 \\
23 \\
\end{array}$ & $\begin{array}{l}.03 \\
3^{\mathrm{b}} \\
\end{array}$ \\
\hline Residual & 3.408 & 106 & .032 & & \\
\hline Total & 3.700 & 109 & & & \\
\hline
\end{tabular}

Sumber: Data olahan peneliti dari Output SPSS 24.00 (2020)

Dari hasil uji F diatas, dapat diketahui nilai Sig F sebesar 0,033 < 0,050 sehingga dapat disimpulkan bahwa secara simultan terdapat pengaruh yang signifikan dari variabelvariabel independen terhadap corporate social responsibility disclosure. Dengan demikian, model regresi yang digunakan dikatakan layak dan mampu memprediksi corporate social responsibility disclosure.

\section{Hasil Analisis Uji Koefisien Regresi (Uji Statistik t)}

Hasil Uji Koefisien Regresi (Uji t) dapat dilihat pada tabel 5.16. dibawah ini:

Tabel 5.8

Uji Koefisien Regresi (Uji Statistik t)

\begin{tabular}{|c|c|c|c|c|c|}
\hline \multicolumn{6}{|c|}{ Coefficients $^{a}$} \\
\hline \multirow[t]{2}{*}{ Model } & \multicolumn{2}{|c|}{$\begin{array}{l}\text { Unstandardiz } \\
\text { ed } \\
\text { Coefficients }\end{array}$} & \multirow{2}{*}{\begin{tabular}{l} 
Standardize \\
d \\
Coefficient \\
s \\
\multicolumn{1}{c}{ Bet } \\
a \\
\end{tabular}} & \multirow[t]{2}{*}{$\mathrm{t}$} & \multirow[t]{2}{*}{ Sic } \\
\hline & B & $\begin{array}{l}\text { Std. } \\
\text { Error }\end{array}$ & & & \\
\hline 1 ) (Constant & .545 & .094 & & $\begin{array}{r}5.77 \\
8 \\
\end{array}$ & .000 \\
\hline Board_Dir & -.022 & .009 & -.221 & $\begin{array}{r}2.32 \\
8 \\
\end{array}$ & .022 \\
\hline $\begin{array}{l}\text { Age_Com } \\
\mathrm{p}\end{array}$ & -.002 & .002 & -.107 & $\begin{array}{r}1.09 \\
3 \\
\end{array}$ & .277 \\
\hline Pub_Own & .001 & .001 & .072 & .749 & .455 \\
\hline
\end{tabular}

Sumber: Data olahan peneliti dari Output SPSS 24.00 (2020)

Berdasarkan hasil output pada tabel diatas, maka hasil pengujian hipotesis pada penelitian ini adalah sebagai berikut:

\section{Pengaruh Ukuran Dewan Direksi tehadap} Corporate Social Responsibility Disclosure.

Dari hasil uji t yang dilakukan, ternyata nilai (sig.) dalam tabel coefficient menunjukkan nilai (sig) Ukuran Dewan Direksi 
Jurnal Akuntansi \& Perpajakan, Volume 3, No. 1, Januari 2021

(Board_Dir) sebesar 0,022 $<0,05$ ini berarti lebih kecil dari nilai $\alpha$ yang sebesar 5\%, maka dapat disimpulkan bahwa hipotesis diterima yang berarti Ukuran Dewan Direksi berpengaruh signifikan terhadap corporate social responsibility disclosure.

\section{Pengaruh Umur Perusahaan Terhadap}

Corporate Social Responsibility Disclosure.

Dari hasil uji t yang dilakukan, ternyata nilai (sig.) dalam tabel coefficient menunjukkan nilai (sig) umur peusahaan (Age_Comp) sebesar 0,277>0,05 ini berarti lebih besar dari alpha $(\alpha) 5 \%$, maka dapat disimpulkan bahwa hipotesis ditolak yang berarti umur perusahaan-perusahaan di Indonesia yang menjadi sampel pada penelitian ini tidak berpengaruh terhadap corporate social responsibility disclosure.

\section{Pengaruh Kepemilikan Saham Publik tehadap Corporate Social Responsibility}

\section{Disclosure}

Dari hasil uji t yang dilakukan, ternyata nilai (sig.) dalam tabel coefficient menunjukkan nilai (sig) Kepemilikan Saham Publik (Pub_Own) sebesar $0,455>0,05$ ini berarti lebih besar dari alpha $(\alpha)$ 5\%. Maka dapat disimpulkan bahwa hipotesis ditolak yang berarti kepemilikan saham publik tidak berpengaruh terhadap Corporate Social Responsibility Disclosure.

\section{Uji Koefisien Determinasi}

Koefisien determinasi $\left(\mathrm{R}^{2}\right)$ pada intinya mengukur seberapa jauh kemampuan model dalam menerangkan variasi variabel dependen. Nilai koefisien determinasi antara nol dan satu. Nilai $\mathrm{R}^{2}$ yang kecil berarti kemampuan variabel-variabel independen dalam menjelaskan variasi variabel dependen amat terbatas (Ghozali,2018). Nilai koefisien determinasi terletak pada tabel summary pada kolom $\mathrm{R}$ Square. Berikut ini akan ditampilkan hasil dari uji koefisien determinasi regresi linear berganda:

Tabel 4.9

Hasil Uji Koefisien Determinasi

\begin{tabular}{|c|c|c|c|c|}
\hline \multicolumn{5}{|c|}{ Model Summary } \\
\hline Mode & $\mathrm{R}$ & R Square & $\begin{array}{l}\text { Adjuste } \\
\text { d R } \\
\text { Squa } \\
\text { re }\end{array}$ & $\begin{array}{l}\text { Std. Error of } \\
\text { the } \\
\text { Estimate }\end{array}$ \\
\hline 1 & .281 & $\begin{array}{l}.17 \\
9\end{array}$ & .253 & $\begin{array}{l}.1793092 \\
7^{2}\end{array}$ \\
\hline
\end{tabular}

Sumber: Data olahan

peneliti dari Output SPSS

$24.00(2020)$

Pada tabel diatas menunjukkan bahwa nilai Adjusted $\mathrm{R}$ Square $\left(\mathrm{R}^{2}\right)$ sebesar 0.253 , hal ini dapat diartikan bahwa $25,3 \%$ variasi Corporate Social Responsibility Disclosure pada penelitian ini dapat dijelaskan oleh ketiga variabel independen yang digunakan 
Jurnal Akuntansi \& Perpajakan, Volume 3, No. 1, Januari 2021

pada penelitian ini. Sisanya sebesar $74,7 \%$ dapat dijelaskan oleh variabel-variabel lainnya di luar model pada penelitian ini yang tidak dimasukkan dalam model regresi.

\section{Analisis Data dan Interpretasi Data \\ Perusahaan}

\section{Pengaruh Ukuran Dewan Direktur} tehadap Corporate Social Responsibility

\section{Disclosure}

Berdasarkan hasil uji t, variabel Ukuran Dewan Direksi berpengaruh signifikan terhadap Corporate Social Responsibility Disclosure. Hal ini sejalan dengan penelitian Eriandani (2016), yang menyatakan hasil penelitiannya bahwa Ukuran Dewan Direksi memiliki pengaruh yang signifikan terhadap Corporate Social Responsibility Disclosure. Namun penelitian ini tidak sejalan dengan penelitian yang sebelumnya dilakukan oleh Susilowati et al. (2018), yang menyatakan bahwa variabel Ukuran Dewan Direksi tidak memiliki pengaruh terhadap Corporate Social Responsibility Disclosure. Ukuran dewan direksi untuk beberapa perusahaan di Indonesia yang menjadi sampel pada penelitian ini berpengaruh signifikan negatif terhadap Corporate Social Responsibility Disclosure. Hasil penelitian ini menunjukkan bahwa semakin besar ukuran dewan direksi maka pengungkapan Corporate Social Responsibility semakin kecil. Hal ini memperlihatkan bahwa dewan direksi memiliki pertimbangan lain berkaitan dengan keberlangsungan aktivitas operasional perusahaan.

\section{Pengaruh Umur Perusahaan tehadap}

\section{Corporate Social ResponsibilityDisclosure}

Hasil penelitian ini menunjukkan bahwa umur perusahaan baik yang sudah memiliki umur yang lebih lama atau lebih panjang ataupun memliki umur yang masih sedikit atau belum terlalu lama terdaftar di Bursa Efek Indonesia, sama-sama tidak akan mempengaruhi Corporate Social Responsibility Disclosure.. Hal ini menunjukkan bahwa umur perusahaan tidak dapat menjadi tolak ukur untuk luasnya atau lengkapnya Pengungkapan Corporate Social Responsibility yang disusun oleh perusahaan. Hasil Penelitian ini sejalan dengan penelitian yang dilakukan oleh Wulandari et al. (2018), yang menyatakan hasil penelitiannya bahwa umur perusahaan untuk beberapa perusahaan di Indonesia yang menjadi sampel pada penelitian ini tidak dapat mempengaruhi Corporate Social Responsibility Disclosure. Tetapi hasil penelitian ini tidak sejalan dengan hasil penelitian yang dilakukan oleh Pradana \& Suzan (2016) dan Herawati (2015), yang menyatakan bahwa umur perusahaan memiliki pengaruh secara signifikan 
Jurnal Akuntansi \& Perpajakan, Volume 3, No. 1, Januari 2021

terhadap Corporate Social Responsibility

Disclosure.

\section{Pengaruh Kepemilikan Saham Publik}

\section{tehadap Corporate Social Responsibility}

\section{Disclosure.}

Hasil penelitian ini menunjukkan bahwa kepemilikan saham publik baik dalam jumlah yang banyak ataupun sedikit tidak akan mempengaruhi pengungkapan corporate social responsibility. Hasil penelitian ini sejalan dengan penelitian yang dilakukan oleh Aprifa \& Ardiyanto (2017), dimana hasil penelitiannya menyatakan bahwa kepemilikan saham publik tidak berpengaruh terhadap pengungkapan corporate social responsibility. Hal ini berarti jumlah kepemilikan saham publik dalam jumlah yang kecil ataupun besar tidak akan mempengaruhi tingkat pengungkapan tanggung jawab sosial perusahaan. Keadaan ini memperlihatkan kurangnya perhatian perusahaan kepada kepentingan pemilik saham publik. Hasil penelitian ini tidak sesuai dengan hasil penelitian yang dilakukan oleh Hamdani et al. (2017) dan Indraswari \& Astika (2014), yang menyatakan bahwa kepemilikan saham publik berpengaruh signifikan terhadap pengungkapan tanggung jawab sosial perusahaan (corporate social responsibility disclosure).

\section{V.SIMPULAN DAN SARAN}

\section{Simpulan}

Berdasarkan hasil penelitian dan pembahasan yang telah dilakukan dapat ditarik kesimpulan:

1) Ukuran Dewan Direksi pada perusahaan di Indonesia memiliki pengaruh yang signifikan dan positif terhadap pengungkapan tanggungjawab sosial perusahaan (corporate social responsibility disclosure). Jumlah anggota dewan direksi yang cukup besar diyakini oleh beberapa perusahaan yang ada di Indonesia akan membantu manajemen perusahaan di dalam pengambilan keputusan strategis di dalam menjalankan usahanya, karena itu sedikit banyak akan mempengaruhi pengungkapan laporan tanggungjawab sosial perusahaan (corporate social responsibility).

2) Umur perusahaan untuk beberapa perusahaan yang terdaftar pada pasar modal di Indonseia tidak memiliki pengaruh yang signifikan terhadap corporate social responsibility disclosure. Hal ini diyakini tidak akan membantu manajemen perusahaan di dalam pengambilan keputusan 
Jurnal Akuntansi \& Perpajakan, Volume 3, No. 1, Januari 2021

strategis di dalam menjalankan usahanya, karena itu sedikit banyak akan mempengaruhi pengungkapan laporan pertanggungjwaban sosial perusahaan (corporate social responsibility).

3) Kepemilikan saham publik yang ada di setiap perusahaan yang terdaftar pada pasar modal yang ada di Indonesia tidak memiliki pengaruh yang signifikan terhadap pengungkapan laporan tanggung jawab sosial perusahaan (corporate social responsibility disclosure) Perusahaan yang terdaftar di pasar modal Indonesia, baik yang sahamnya sedikit ataupun banyak untuk kepemilikan saham publiknya diyakini tidak mempengaruhi secara signifikan terhadap pengungkapan tanggungjawab sosial perusahaan (corporate social responsibility disclosure)

\section{Saran}

Berdasarkan pembahasan dan kesimpulan yang didapat maka peneliti menyarankan beberapa hal yang diharapkan dapat membantu pihak manajemen perusahaan di dalam meningkatkan pengungkapan tanggungjawab sosial perusahaan (Corporate Social Responsibility). Saran yang diberikan oleh peneliti sebagai berikut:

1. Penelitian berikutnya disarankan dapat menambahkan variabel-variabel lain yang mempengaruhi Corporate Social Responsibility Disclosure yaitu seperti: keanekaragaman dewan direksi, keanekaragaman dewan komisaris, komite audit, dan lainnya lagi yang dapat menjadi faktor-faktor yang mempengaruhi Corporate Social Responsibility..

2) Penelitian selanjutnya dapat meneliti data laporan keuangan di Negara lain selain yang diteliti pada penelitian ini di Negara Indonesia seperti data laporan keuangan perusahaan yang terdaftar di Bursa Efek Malaysia, Singapura ataupun negara dunia lainnya.

3) Penelitian selanjutnya diharapkan untuk dapat menggunakan model pengukuran di dalam Corporate Social Responsibility yang lain, bukan pengukuran dengan standard GRI4 seperti yang dilakukan di dalam penelitian ini, sehingga dapat memberikan variasi dalam pengukuran Corporate Social Responsibility Disclosure yang dapat digunakan untuk penelitian bidang 
Jurnal Akuntansi \& Perpajakan, Volume 3, No. 1, Januari 2021

akuntansi manajemen.

4) Peneliti selanjutnya diharapkan juga dapat menambahkan periode penelitian menjadi lebih dari 5 (lima) tahun seperti pada penelitian ini, sebaiknya 5 tahun keatas, yaitu 8 (delapan) tahun pengamatan untuk data penelitiannya.

\section{DAFTAR PUSTAKA}

Aprifa, M., \& Ardiyanto, M.D. (2017). Pengaruh Karakteristik Perusahaan dan Board Diversity Terhadap Tingkat Corporate Social Responsibility Disclosure (Studi Empiris Pada Perusahaan Manufaktur yang Terdaftar di Bursa Efek Indonesia Tahun 2011- 2015). Dipenogoro Journal Of Accounting., 6(3), 2337-3806.

Budiman, N. (2015). Faktor-Faktor Yang Mempengaruhi Pengungkapan Tanggung Jawab Sosial Perusahaan. Jurnal Riset Akuntansi Mercu Buana (JRAMB), 1(1), 14-34.

Ciriyani, N.K., \& Putra, I.M.P.D. (2016). Pengaruh Ukuran Perusahaan, Profitabilitas, dan Umur Perusahaan Pada Pengungkapan Informasi Lingkungan. E-Jurnal Akuntansi Universitas Udayana, 17(3), 2091-2119.

Dermawan, D., \& Deitiana, T. (2014). Faktor-Faktor Yang Mempengaruhi Pengungkapan Corporate Social Responsibility. Jurnal Bisnis dan Akuntansi, 16(2), 158-165.

Dewi, Sofia Prima., dan Keni. (2013).
Pengaruh Umur Perusahaan, Profitabilitas, Ukuran

Perusahaan,dan Leverage

Terhadap Pengungkapan

Tanggung Jawab Sosial Perusahaan. Jurnal Bisnis dan Akuntansi, Vol. 15 No.1, Hlm 112.

Dyduch, J. \& Krasodomska, J. (2017). Determinants of Corporate Social Responsibility Disclosure : An Empirical Study Of Polish Listed Companies. Sustainability, 1-24.

Eriandani, R. dan Kuswanto, C. (2016). Apakah Komposisi Dewan Direksi dan Dewan Komisaris Mempengaruhi Pengungkapan Corporate Social Responsibility (CSR?. Jurnal Eksapansi, Vol. 8, No. 2, pp. 213-227.

Fatoni, Andini R., \& Rahardjo, K. (2016). Pengaruh Kepemilikan Publik, Return On Equity, Current Ratio, Umur Perusahaan dan Company Size Terhadap Pengungkapan Corporate Social Responsibility Pada Perusahaan Real Estate and Property Yang Terdaftar Di Bursa Efek Indonesia Periode 2011-2014. Journal of Accounting, 2(2).

Felicia, M., \& Rasmini, N.K. (2015). Faktor-Faktor Yang Mempengaruhi Pengungkapan Corporate Social Responsibility Pada Perusahaan Yang Terdaftar Di BEI. E-Jurnal Akuntansi Universitas Udayana, 12(2), 143153.

Ferdinan, A. (2014). Metode Penelitian Manajemen. Semarang: Badan Penerbit Universitas Dipenogoro.

Ghozali, I. (2016). Aplikasi Analisis 
Jurnal Akuntansi \& Perpajakan, Volume 3, No. 1, Januari 2021

Multivariate dengan Program IBM SPSS 23 Edisi 8.

Semarang: Badan Penerbit Universitas Dipenogoro.

Hadi, N. (2014). Corporate Social Responsibility. Yogyakarta: Graha Ilmu.

Hamdani, S.P., Yuliandari, W.S., \& Budiono, E. (2017). Pengaruh kepemilikan Saham Publik dan Return On Assets Terhadap Pengungkapan Corporate Social Responsibility. Jurnal Riset Akuntansi Kontemporer, 9(1), 4454.

Indraswari, G.A.D., \& Astika, I.B.P. (2015). Pengaruh Profitabilitas, Ukuran Perusahaan, dan Kepemilikan Saham Publik Terhadap Pengungkapan CSR. EJurnal Akuntansi Universitas Udayana, 11(1), 289-302.

Mansaray, A.P., Yuanyuan, L., \& Brima, S. (2017). The Impact of Corporate Social Responsibilty Disclosure on Financial Performance of Firms in Africa. International Journal of Economics and Financial Issues, 7(5), 137-146.

Pradana, F.A., \& Suzan, L. (2016). Pengaruh Struktur Kepemilikan, Ukuran Perusahaan, dan Umur Perusahaan Terhadap Pengungkapan Corporate Social Responsibility (CSR). EProceeding Of Management, 3(1), 339-347.

Pradnyani, I.G.A.A., \& Sisdyani, E.A. (2015). Pengaruh Ukuran Perusahaan, Profitabilitas, Leverage, Dan Ukuran Dewan Komisaris Pada Pengungkapan Tanggung Jawab Sosial
Perusahaan. E-Jurnal Akuntansi Universitas Udayana, 11(2), 384397.

Pramesti, G. (2014). Kupas Tuntas Data Penelitian dengan SPSS 22. Jakarta: Elex Media Komputindo.

Rahayu, P., \& Anisyukurlillah, I. (2015). Pengaruh Kepemilikan Saham Publik, Profitabilitas dan Media Terhadap Pengungkapan Tanggung Jawab Sosial. Accounting Analysis Journal, 4(3).

Rahmayanty, S. (2015). Pengaruh Size Perusahaan, Kepemilikan Saham Publik, Kepemilikan Saham Asing, Dan Profitabilitas Perusahaan Terhadap Pengungkapan Corporate Social Responsibility (CSR) Pada Perusahaan Food And Beverages Yang Terdaftar Di BEI Pada Tahun 2010-2013. Jom FEKON, 2(2).

Saputra, S.E. (2016). Pengaruh Leverage, Profitabilitas, Dan Size Terhadap Pengungkapan Corporate Social Responsibility Pada Perusahaan Di Bursa Efek Indonesia. Journal of Economic and Economic Education, 5(1), 75-89.

Sudjana, N.L.A.S., \& Sudana, I.P. (2017). Faktor-Faktor Yang Mempengaruhi Pengungkapan CSR Dengan Profile Perusahaan Sebagai Variabel Pemoderasi. EJurnal Akuntansi Universitas Udayana, 19(3), 2468-2495.

Sugiyono. (2014). Metode

Penelitian Kuantitatif Kualitatif dan

$R \& D$. Bandung: Alfabeta. 
Jurnal Akuntansi \& Perpajakan, Volume 3, No. 1, Januari 2021

Sugiyono. (2015). Statistika untuk

Penelitian. Bandung: Alfabeta.

Sunaryo, B.A., \& Mahfud, M.K. (2016). Pengaruh Size, Profitabilitas, Leverage dan Umur Terhadap Pengungkapan Tanggung Jawab Sosial Perusahaan (Studi Empiris Perusahaan Manufaktur yang Listing di BEI Tahun 2010 2013). Dipenogoro Journal of Management, 5(2), 1-14.

Sunyoto, D. (2016). Metodologi Penelitian Akuntansi. Bandung: Refika Aditama.

Susilowati, K. D. S., Candrawati, T., dan Aang Afandi (2018). Analisis Pengaruh Ukuran Perusahaan, Profitabilitas, dan Ukuran Dewan Direksi Terhadap Pengungkapan Tanggung Jawab Sosial Perusahaan (Studi Kasus Pada Perusahaan Makanan dan Minuman di Indonesia). Jurnal Ilmu Manajemen, Volume 4, Nomor2, pp. 62-82.

Kartika Dewi Sri Susilowati, Triesti

Candrawati, Aang Afandi

Swandari, F., \& Sadikin, A. (2016). The Effect Of Ownership Structure, Profitability, Leverage, And Firm Size On Corporate Social Responsibilityn(CSR). Binus Business Review, 7(3), 315-320.

Trinanda, S.M., Yahdi.M., \& Rizal, N. (2018). Analisis Pengaruh Size, Profitabilitas Dan Leverage Terhadap Corporate Social Responsibility Disclosure (Studi Empiris Pada Perusahaan Jasa Sektor Property Dan Real Estate Yang Terdaftar Di Bursa Efek Indonesia Tahun 2016). Progress Conference, 1(1).
Widyastari, Ni Kadek Widnyani. (2018). Pengaruh Ukuran Perusahaan, Proporsi Dewan Komisaris Independen, dan Kepemilikan Asing Pada Pengungkapan Corporate Social Responsibility. ISSN: 2302-8556.

Wulandari, W. (2018). Pengaruh Ukuran Perusahaan, Umur Perusahaan, Ukuran Dewan Komisaris,Profitabilitas dan Leverage Terhadap Pengungkapan Tanggung Jawab Sosial Perusahaan (Studi Empiris Pada Perusahaan BUMN yang terdaftar di Bursa Efek Indonesia pada Tahun 2013-2015). JOM $F E B, 1(1)$ 